\title{
Thuja occidentalis L. (Cupressaceae): Ethnobotany, Phytochemistry and Biological Activity
}

\author{
Sonia Caruntu ${ }^{1,+}$, Alina Ciceu ${ }^{2,+}$, Neli Kinga Olah ${ }^{1}{ }^{\mathbb{D}}$, Ioan Don ${ }^{3,4}$, Anca Hermenean ${ }^{2, *}$ \\ and Coralia Cotoraci ${ }^{5}$ \\ 1 Faculty of Pharmacy, Vasile Goldis Western University of Arad, Rebreanu 86, 310414 Arad, Romania; \\ sonia.caruntu@gmail.com (S.C.); neliolah@yahoo.com (N.K.O.) \\ 2 "Aurel Ardelean" Institute of Life Sciences, Vasile Godis Western University of Arad, Rebreanu 86, \\ 310414 Arad, Romania; alina_ciceu@yahoo.com \\ 3 "Pavel Covaci" University Botanical Garden from Macea, Vasile Goldis Western University of Arad, \\ Rebreanu 86, 310414 Arad, Romania; don_ioan@yahoo.com \\ 4 Faculty of Economics, Computer Science and Engineering, Vasile Godis Western University of Arad, \\ Rebreanu 86, 310414 Arad, Romania \\ 5 Faculty of Medicine, Vasile Goldis Western University of Arad, Rebreanu 86, 310414 Arad, Romania; \\ ccotoraci@yahoo.com \\ * Correspondence: anca.hermenean@gmail.com \\ $\dagger$ These authors contributed equally to this work.
}

Academic Editor: Cristina Forzato

Received: 13 October 2020; Accepted: 17 November 2020; Published: 19 November 2020

\begin{abstract}
Thuja occidentalis L. (Cupressaceae) has its origins in Eastern North America and is cultivated in Europe and Brazil as an ornamental tree, being known as the "tree of life" or "white cedar". In traditional medicine, it is commonly used to treat liver diseases, bullous bronchitis, psoriasis, enuresis, amenorrhea, cystitis, uterine carcinomas, diarrhea, and rheumatism. The chemical constituents of T. occidentalis have been of research interest for decades, due to their contents of essential oil, coumarins, flavonoids, tannins, and proanthocyanidines. Pharmacology includes antioxidant, anti-inflammatory, antibacterial, antifungal, anticancer, antiviral, protective activity of the gastrointestinal tract, radioprotection, antipyretic, and lipid metabolism regulatory activity. Therefore, the present review represents the synthesis of all the relevant information for T. occidentalis, its ethnobotany, phytochemistry, and a thorough analysis of their pharmacological activities, in order to promote all the biological activities shown so far, rather than the antitumor activity that has promoted it as a medicinal species.
\end{abstract}

Keywords: Thuja occidentalis L.; thujone; ethnobotany; pharmacology; biological activities

\section{Introduction}

The approach of various complementary therapies is becoming an increasingly used method of treatment. In this context, the use of plants for the treatment of various diseases plays a major role [1-3]. Folk medicine is widely used in much of the world, even though it is not officially recognized in many countries [4]. Over $80 \%$ of the population in Africa and Asia use plants and plant extracts for the treatment of various diseases [5].

The use of phytomedicine began in China during the Xia dynasty and in India during the Vedic times. Herbal remedies are growing in popularity around the world for several reasons: They have long-lasting curative effects and are characterized by effectiveness, safety, and low side effects [6,7]. Currently, ethnopharmacological studies are encouraged worldwide as a method for highlighting species containing molecules or beneficial products that can be used in the pharmaceutical, 
dietary, and cosmetic fields [8,9]. The use of medicinal plants has increased significantly in Western countries due to the adverse effects of chemical drugs and significant financial benefits. Although it is difficult to estimate the exact amount earned from the trade in plants and plant extracts, it is certain that the pharmaceutical industry based on folk medicine grows annually by over $4 \%[10,11]$.

Medicinal plants are a source of bioactive natural compounds with high therapeutic potential. Today, biologically active compounds in plants and their derivatives are found in a high percentage in drugs on the pharmaceutical market. It is estimated that about $25 \%$ of current drugs are composed of natural compounds [12]. Moreover, more and more food supplements and cosmetics contain various plant extracts and biologically active compounds as main active ingredients [13].

The importance of medicinal plants is due to the great diversity of bioactive molecules with beneficial effect, as well as phenolic compounds, carotenoids, tocopherols, and vitamins. Due to their antioxidant properties, bioactive compounds are increasingly being studied for their beneficial effects against many chronic conditions, such as obesity, diabetes, and cancer [14-17]. Some bioactive compounds react slowly and need a long time to exert their antioxidant action. Moreover, the synergism between biomolecules in a mixture makes the target effect not only dependent on concentration, but also on the interaction between antioxidants $[18,19]$. In recent years, there has been an increase in the number of preclinical and clinical studies aimed at testing the use of plant extracts and biologically active compounds with beneficial effects on human health [20].

Thuja trees belongs to the order Pineales, in the Cupressaceae family [21]. The Thuja genus contains five species: Thuja koraiensis, Nakai-Korean thuja; Thuja occidentalis L., eastern arborvitae, northern white cedar; Thuja plicata Donn ex D. Don, Western red cedar; Thuja standishii (Gordon), Carrière-Japanese thuja; and Thuja sutchuenensis, Franch-Sichuan thuja. They are evergreens trees growing from 3 to $60 \mathrm{~m}$ tall with flattened branchlets, distributed in North America and East Asia.

The leaves of T. koraiensis have a high content of vitamin C, being used by the American natives and the first European explorers as a treatment for scurvy. The leaves of this tree have also been used as a treatment for rheumatism [22]. T. koraiensis oil is a known remedy with topical application in the treatment of the human papilloma virus (HPV), as well as for genital or common warts treatment [23], as an antioxidant [24], and for antibacterial properties [22].

Due to its antimicrobial and insecticidal properties, T. plicata essential oil has traditionally been used for wood preservation and insect repellent [25-27]. T. plicata leaf oil has traditionally been used by Aborigines in the Pacific Northwest, to treat a number of upper respiratory tract diseases [25]. Moreover, its essential oil has antibacterial and antifungal activity [26]. Its antimicrobial effect is thought to be due to the high concentration of $\alpha$ - and $\beta$-thujone, the main biologically active compounds in various essential oils that possess similar antimicrobial properties $[28,29]$.

T. standishii is also used for its medicinal properties for the treatment of Epstein-Barr virus [30,31] and for antitumor activity [32].

The summary of the bioactive potential of the Thuja species, according to its applications, is presented in Table 1.

The present work provides an overview about the state-of-the-art in ethnobotany, phytochemistry, and a detailed analysis of the pharmacological properties of T. occidentalis, such us: antioxidant, anti-inflammatory, antibacterial, antifungal, anticancer, antiviral, protective activity of the gastrointestinal tract, radioprotection, antipyretic, and lipid metabolism regulatory activity, in order to promote all the biological activities shown so far, rather than the antitumor activity that has promoted it as a medicinal species. 
Table 1. Comparison of the bioactive potential of T. occidentalis with other Thuja genus species.

\begin{tabular}{|c|c|c|}
\hline \multirow{2}{*}{ Thuja Species } & \multicolumn{2}{|c|}{ Benefits According to Biological Activities } \\
\hline & Medicinal Use & Industrial Use \\
\hline T. koraiensis & antimicrobial $[22,23]$; antioxidant $[24]$ & - \\
\hline T. occidentalis & $\begin{array}{l}\text { antimicrobial [26,33-35]; antioxidant and } \\
\quad \text { anti-inflammatory [33,36-40]; } \\
\text { antitumor [41-44]; hepatoprotective and } \\
\text { gastroprotective [45,46]; antidiabetic [47]; } \\
\quad \text { antiatherosclerotic [48]; } \\
\text { radioprotective [49]; antipyretic [50] }\end{array}$ & $\begin{array}{l}\text { antifungal agent for } \\
\text { biocontamination control in } \\
\text { libraries and archives storage } \\
\text { areas [51]; insecticidal activity [52] }\end{array}$ \\
\hline T. plicata & $\begin{array}{l}\text { antimicrobial }[25,26,53] \text {; } \\
\text { anti-inflammatory, immunomodulatory, } \\
\text { and tissue remodeling [54] }\end{array}$ & $\begin{array}{c}\text { antimicrobial agent for } \\
\text { decontamination of buildings [25] }\end{array}$ \\
\hline T. standishii & antimicrobial [30-32]; antitumor [30-32] & - \\
\hline T. sutchuenensis & antimicrobial $[55,56]$ & - \\
\hline
\end{tabular}

\section{Ethnobotany}

Thuja occidentalis originated in the Eastern North America and is cultivated in Europe and Brazil as an ornamental tree [57-59], known as the "tree of life" or "white cedar" (Figure 1) [21].



Figure 1. Specimen of T. occidentalis from the "Pavel Covaci" University Botanical Garden of Macea, Romania; detail: twig of leaves showing the flattened branches (a) and small pins containing the seeds (b).

In traditional medicine, T. occidentalis has been used in the treatment of liver diseases, bullous bronchitis, psoriasis, enuresis, amenorrhea, cystitis, uterine carcinomas, diarrhea, and rheumatism [58,60-62]. Essential leaf oil was used in the treatment of fungal infections, cancer, and intestinal worms [41]. As a tincture, T. occidentalis has been used in the treatment of warts, papillomas, and condylomas caused by human papilloma virus (HPV) $[57,63]$.

Since historical times, the essential oil of T. occidentalis has been used in folk medicine. T. occidentalis containing thujone was used for hepatoprotection, bronchial catarrh, rheumatism, psoriasis, and even uterine carcinomas. 
The mother tincture of $T$. occidentalis is used in homeopathy against a number of diseases. Homeopathy uses thuja as one of the main remedies for psychotic constitutions, in case of snake bite, small-pox, and vaccination-induced toxicity, respectively the proliferation or pathological vegetation [64].

Thuja preparations with thujone were regularly used by the American Indian traditional healers. The decoct and the tea prepared from the inner bark of the unwoody twigs could relieve constipation and headache [65]. It has also been used for the treatment of polyps, birthmarks, and wounds and as a painkilling and anthelmintic remedy $[66,67]$.

\section{Phytochemistry}

The chemical composition of the Thuja occidentalis is summarized in Table 2.

Table 2. The chemical composition of the fresh and dried T. occidentalis.

\begin{tabular}{|c|c|}
\hline \multicolumn{2}{|c|}{ Chemical Composition of the Fresh Plant } \\
\hline Essential oil $(v / w)$ & \\
\hline $\begin{array}{l}\text { Essential oil compounds (mainly monoterpenes): } \\
\text { thujone }(65 \%) \text {; isothujone }(8 \%) \text {; fenchone }(8 \%) \\
\text { sabines }(5 \%) ; \alpha \text {-pinene }(2 \%)\end{array}$ & $0.6 \%$ \\
\hline Reducing sugar & $2.07 \%$ \\
\hline Minerals & $2.11 \%$ \\
\hline Free acids & $1.67 \%$ \\
\hline Tannic agents & $1.31 \%$ \\
\hline \multicolumn{2}{|c|}{ The Constituents of the Dried Herbal Substance (Thuja occidentalis Herbal) } \\
\hline \multirow{8}{*}{ Essential oil } & Borneol \\
\hline & Camphene \\
\hline & Fenchone \\
\hline & Limonene \\
\hline & Myricene \\
\hline & $\alpha$-Terpine \\
\hline & Terpinolene \\
\hline & $\begin{array}{c}\text { Thujone (85\% } \alpha \text {-thujone and } 15 \% \beta \text {-thujone) is the } \\
\text { main compound }(0.76-2.4 \%)\end{array}$ \\
\hline Coumarins & $\begin{array}{c}p \text {-Coumaric acid } \\
\text { Umbelliferone }\end{array}$ \\
\hline \multirow{7}{*}{ Flavonoids } & Kaempferol \\
\hline & Kaempferol-3-O- $\alpha$-rhamnoside \\
\hline & Mearnsitrin \\
\hline & Myricetine \\
\hline & Myricitrin \\
\hline & Quercetin \\
\hline & Quercitrin \\
\hline \multirow{2}{*}{ Tannins } & Catechine \\
\hline & Gallocatechine \\
\hline Proanthocyanidines & $\begin{array}{l}\text { Procyanidin B-3 } \\
\text { Prodelphinidin }\end{array}$ \\
\hline
\end{tabular}

The fresh plant contains approximately $0.6 \%$ essential oil (EO), 2.07\% reducing sugars, $4.9 \%$ polysaccharides, $2.11 \%$ minerals, $1.67 \%$ free acids, and $1.31 \%$ tannic agents [68]. The main monoterpenes identified in the EO obtained from fresh leaves are $65 \%$ thujone, $8 \%$ isothujone, $8 \%$ fenchone, $5 \%$ sabines, and $2 \% \alpha$-pinene [68]. Other identified monoterpenes are: carvotanacetone, origanol, origanes, myrcen, and camphen [68-71].

Moreover, high molecular weight glycoproteins or polysaccharides have been shown to be particularly relevant for plant activity [72]. 
The dry plant has 1.4-4\% EO, whose constituents are borneol, camphene, fenchone, limonene, myricene, $\alpha$-terpine, terpinolene, thujone, thujylalcohol. Thujone consists of $85 \% \alpha$-thujone and $15 \% \beta$-thujone is the main compound $(0.76-2.4 \%)$ found in the EO obtained from the dry plant. Other compounds present in the dry plant are coumarins, represented by $p$-coumaric acid and umbelliferone; flavonoids, e.g., kaempferol, kaempferol-3-O- $\alpha$-rhamnoside, mearnsitrin, myricetin, myricitrin, quercetin, and quercitrin; and tannins, (+/-)-catechins, (-)-gallocatechin, and proanthocyanidines, like pocyanidin B-3 and prodelphinidin.

Other constituents are tannic acid, which is about $1.3 \%$, as well as polysaccharides and proteins representing approximately $4 \%[58,68,73-78]$. Nazir et al. (2016) have found that the T. occidentalis leaf methanolic extract contains $135.32 \mathrm{mg} / \mathrm{g}$ total polyphenols expressed in gallic acid equivalent and $3.46 \mathrm{mg} / \mathrm{g}$ of total flavonoids expressed in quercitin equivalent [36].

Thujone is the monoterpene found in the composition of many plants including Thuja occidentalis. However, the use of this compound is regulated by the European Parliament and Council and the European Medicines Agency [67]. The isomers $\alpha$-thujone and $\beta$-thujone are monoterpene ketones, with the following IUPAC name: $(1 S, 4 R, 5 R)-4$-methyl-1-(propane-2-yl) bicyclo (3.1.0) hexan-3-one [67].

In a previous study, we found, in an ethanolic extract made from fresh leaves, $21.13 \mu \mathrm{g} / \mathrm{mL}$ thujone, $2.16 \mathrm{mg} / \mathrm{mL}$ total phenolic acids expressed in caffeic acid, $0.36 \mathrm{mg} / \mathrm{mL}$ total flavonoids expressed in rutoside, respectively [37].

However, to date, the genetic regulation of thujone synthesis pathway has been studied in two species: Salvia officinalis and Thuja plicata. Geranyldiphosphate (GPP) and neryl-diphosphate are the general precursors' starting points and follow a four-step pathway. Sabinene is the first monoterpene in this path, being catalyzed by the enzyme sabinene-synthase (SS). It has been showed that sabinene is the precursor of thujone in S. officinalis, A. absinthium, and T. vulgare. Next, in three consecutive steps, thujone is formed from sabinene. The next intermediary in thujones' synthesis is sabinone, from which begins the thujone synthesis. There are some corresponding enzymes of this transformation which have not yet been clarified and also the formation of the two isomers of thujone ( $\alpha$ and $\beta$ ). There are some species who get both isomers, while other plants accumulate just one of them [67].

\section{Biological Activities}

Thuja occidentalis L. presents a varied range of pharmacological activities, such as antioxidant activity [36,38], anti-inflammatory [21], antibacterial, antifungal [26,33,79-82], antitumoral [42-44,63,83-85], antidiabetic [47], hypolipidemic, antiatherosclerotic [48], gastroprotective [45], antiviral, immunostimulent [73-75], radioprotector [49,86], and sedative [87]. Pharmacological and clinical investigations have started to use the effects of thujone biological activities.

\subsection{Antioxidant Activity}

The antioxidant capability is the best described property of phenolic compounds toward free radicals which are produced by cells metabolism [88].

In our previous studies, we showed a high antioxidant activity of a mother tincture of Thuja occidentalis by 2,2-diphenyl-1-picrylhydrazyl radical (DPPH) containing (3.9 mg GAE/g d.w.) polyphenols, as well as its in vitro antioxidant capacity on Caco-2 cells exposed to oxidative stress induced by $\mathrm{H}_{2} \mathrm{O}_{2}$, by MDA- and GSH-level assessments [37].

Nazir et al. (2016) showed that the antioxidant potential of the Thuja occidentalis methanolic extract was assumed to high DPPH radical scavenging activities, ABTS, NO and lipid peroxidation assays [36].

In their study, Mighri et al. (2010) examined the antioxidant and antimicrobial activity of four essential oil types, whose major constituents were $\beta$-thujone, $\alpha$-thujone, $\alpha$-thujone/ $\beta$-thujone, and 1,8-cineole/camphor/ $\alpha$-thujone/ $\beta$-thujone, and the composition was investigated by using capillary GC and GC/MS technique. The results of the study showed that all examined oils had a great antimicrobial potential, and, in addition, they assessed the antioxidant capacity by different in vitro 
tests [89]. Moreover, in a study, Mahomoodally et al. (2019) assessed the antioxidant potential, antiglycation, and the total phenolics content of essential oils extracted from 19 medicinal plants [90].

The antioxidant potential of T. occidentalis L. cones was assessed in raw chicken ground meat during refrigerated storage in a study made by Yogesh et al. (2014). DPPH free-radical scavenging activity method was used to estimate the antioxidant activity of thuja cones (T. occidentalis) and peach seeds (Prunus persica). They also estimated the total phenolics, flavonoids, and reducing power in these extracts. Thuja cones extract and peach seeds extract had a total phenolics of $7.80 \pm 0.04$ and $1.92 \pm 0.04 \mathrm{mg}$ TAE/g d.w., respectively [39].

Moreover, there has been a remarkable DPPH radical scavenging activity shown by both extracts $(25.52 \pm 1.92 \%$ and $24.99 \pm 0.32 \%)$. However, thuja cones extract showed a better reducing power, as compared to peach seeds extract (3.32 \pm 0.01 and $0.49 \pm 0.01)$ [39].

\subsection{Anti-Inflammatory Activity}

Inflammation is a primary protective reaction that is given to return the damaged tissue due to injurious stimuli. This response involves extravasation of neutrophils through the capillary network and then activation of macrophages, which generate different proinflammatory cytokines, such as TNF- $\alpha$, interleukins, and interferons, which participate in the regulation of inflammatory reactions. There are not many studies that have evaluated the anti-inflammatory activity of T. occidentalis components. The study made by Silva et al. (2017) highlighted the anti-inflammatory activity of the aqueous extract and the polysaccharide fraction obtained from $T$. occidentalis in experimental models of acute inflammation. The doses used were 3,10 , and $30 \mathrm{mg} / \mathrm{kg}$, administered intraperitoneally. They acted through mechanisms that involve modulating mediators, such as histamine, serotonin, PGE2, and bradykinin, and diminishing vascular permeability and neutrophil migration to the affected site. The aqueous extract and the polysaccharide fraction of T. occidentalis reduced production of pro-inflammatory cytokines (TNF- $\alpha$ and IL-6), diminished both COX-2 and iNOS activity, and diminished oxidative stress. High doses of aqueous extract and fraction of polysaccharides obtained from T. occidentalis of $300 \mathrm{mg} / \mathrm{kg}$ did not result in gastric toxicity [21].

Dubey and Barta (2009a) highlighted the antioxidant activity of the ethanolic fraction (EFTO) of $T$. occidentalis in rats. EFTO inhibited lipid peroxidation induced by $\mathrm{FeSO}_{4}$ at doses of 100, 150, 200, 250, and $300 \mu \mathrm{g}$ EFTO [38].

Polysaccharides obtained from thuja leaf extract have been shown to reduce mice-induced inflammation. They have the ability to prevent metastasis by diminishing inflammatory cytokines, such as IL-1 $\beta$, IL-6, granulocyte-macrophage colony stimulating factor (GM-CSF), and TNF- $\alpha$. Moreover, these polysaccharides stimulated the activity of natural killer (NK) cells, cell mediated antibody-dependent cytotoxicity (ADCC) and complement-mediated cytotoxicity (ACC) and stimulated the activity of antitumor factors, IL-2, and TIMP [43].

\subsection{Antibacterial and Antifungal Activity}

T. occidentalis has been shown to have antibacterial properties against a significant number of species, such as Salmonella sp., Enterobacter cloacae, Staphylococcus aureus, Escherichia coli, Pseudomonas aeruginosa, Klebsiella pneumonia, Shigella flexenari, Candida albicans, Proteus vulgaris, Entercoccus faecalis, and Staphylococcus $[79,80]$. They observed that the two components, $\alpha$-thujone and $\beta$-thujone, showed protective effect against Gram-negative bacteria such as Pseudomonas aeruginosa and Klebsiella pneumonia and a mild protective effect against Staphylococcus aureus, Escherichia coli, and Candida albicans [80]. Thuja occidentalis also showed significant antibacterial activity against bacteria and fungi [79]. The antimicrobial profile of essential oil of Thuja occidentalis was also evidenced by Tsiri et al. (2009) [26].

The antifungal properties of $T$. occidentalis have been highlighted against Saccharomyces cerevisiae, Aspergillus parasitious, Aspergillus niger, Aspergillus flavus, Trichophyton rubrum, Macrophomina, and Fusarium solani [81,82]. In the recent study made by Bellili et al. (2018), essential oil extracted from leaves and cones of Thuja occidentalis showed antimicrobial activity against 
Gram-negative bacteria (Escherichia coli, Salmonella typhimurium, Aeromonas hydrophila, and Pseudomonas aeruginosa), Gram-positive bacteria (Staphylococcus aureus, Listeria monocytogenes, and Bacillus cereus), fungus (Aspergillus flavus and Aspergillus niger), and yeast (Candida albicans) [33].

\subsection{Antiviral Activity}

Polysaccharides isolated from $T$. occidentalis have been shown to have antiviral and immunostimulating effect, having the ability to inhibit HIV-1 and influenza A [34,91]. Thuja polysaccharides (TPS) inhibited HIV at a concentration of $625 \mu \mathrm{g} / \mathrm{mL}$. They have been shown not to be toxic to MT-4 cells and have inhibited the expression of HIV-1 specific antigen in newly infected MT-2 cells [91]. Later, Gohla et al. (1992) highlighted the property of the high-molecular-weight polysaccharide fraction from T. occidentalis on HIV-1 [34]. An isolated fraction of T. occidentalis was shown to increase the number of cells producing antibodies in an in vitro study [86].

\subsection{Anticancer Activity}

In homeopathy, $T$. occidentalis is used in the treatment of cancer, but its mechanism of action is not known. Torres et al. (2016) studied the effect of $\alpha / \beta$-thujone on glioblastoma, using in vitro and in vivo models. They have observed that $\alpha / \beta$-thujone has the ability to diminish cell viability and has antiproliferative, proapoptotic, and antiangiogenic properties in vitro. In in vivo studies, $\alpha / \beta$-thujone has been reported to induce regression of neoplasia and inhibited angiogenic markers of VEGF, Ang-4, and CD31 inhibitors in the tumor [42]. The antitumoral effect of the extract obtained from thuja leaves has been evaluated on numerous cancer cell lines $[41,44,63,84]$.

The in vivo study performed by Siveen and Kuttan (2011b) demonstrated the antitumor effect of thujone in the malignant ascites lymphoma model (Dalton). Thujone, a monoterpene naturally found in T. occidentalis, has been shown to increase the number of leukocytes and bone marrow cells. This increased the proliferation of splenocytes and thymocytes, both in the presence and absence of specific mitogenes. Thujone stimulated cell mediated immune response and production of IL-2 and IFN- $\gamma$ [92]. Thujone also showed the ability to inhibit metastasis in melanoma in vivo [83]. Thujone obtained from T. occidentalis ethanolic extract has been shown to have anticancer properties on the malignant melanoma cell line A375. In the same study, thujone was shown to have an antiproliferative effect and the ability to induce apoptosis [41].

Thuja's antitumoral activity has been highlighted in breast cancer [85]. Polysaccharides obtained from T. occidentalis L. leaf extract have been shown to reduce mice-induced inflammation. They have the ability to prevent metastasis by diminishing inflammatory cytokines, such as IL-1 $\beta$, IL-6, granulocyte-macrophage colony stimulating factor (GM-CSF), and TNF- $\alpha$. Moreover, these polysaccharides stimulated the activity of natural killer (NK) cells, cell-mediated antibody-dependent cytotoxicity (ADCC), and complement-mediated cytotoxicity (ACC) and stimulated the activity of antitumor factors, IL-2, and TIMP [43].

\subsection{Protective Activity of the Gastrointestinal Tract}

According to Dubey and Batra (2008b), the ethanol fraction of T. occidentalis showed a hepato-protective effect in acute and chronic liver-induced HCV. The same researchers revealed that the ethanolic fraction of T. occidentalis provides an important effect against gastric lesions [46].

Saeed et al. (2014) evaluated the effect of low dose of T. occidentalis on rabbit, for three months. They carried out an experiment on rabbits, on treated groups with and without tetrachloride. They analyzed the heart, liver, stomach, and kidney tissues histopathologically, on both control groups and T. occidentalis treated groups. They also tested the $\mathrm{CCl}_{4}$ injected group by doing the liver function test. Their study showed that there were minor harmful effects in the liver and kidney tissues which were treated with carbon tetrachloride, but there was no major toxicity due to the antioxidant effect of active constituents from T. occidentalis [93]. 
The methanolic extract obtained from T. occidentalis orally administered at $200 \mathrm{mg}$ and $400 \mathrm{mg} / \mathrm{kg}$ body weight has been shown to have gastroprotective effect in rats, comparable to omeprazole. This extract reduced gastric acid production by $45 \%$ and $69 \%$, respectively, and favored a significant regeneration of the gastric epithelium at a dose of $400 \mathrm{mg} / \mathrm{kg}$ body weight. The antiulcer action of this extract is due to its antioxidant properties [45].

Our previous results show that orally administration of T. occidentalis mother tincture by gavage, for one week, to mice with experimentally induced ulcerative colitis, succeeded in inhibiting the inflammatory process induced by TNBS in the intestine, and normalized the structure and ultrastructure of the intestinal mucosa [37].

\subsection{Lipid Metabolism Regulation}

The ethanolic fraction of T. occidentalis has been shown to have hypoglycemic properties in rats with aloxan-induced diabetes, at a dose of $200 \mathrm{mg} / \mathrm{kg}$, without significant impact on body weight. It has also improved lipid profile and has been shown to have a protective effect against oxidative stress by increasing glutathione level in blood [47].

In the study conducted by Dubey and Batra (2009a), the T. occidentalis ethanolic fraction administered at doses of $200 \mathrm{mg}$ and $400 \mathrm{mg} / \mathrm{kg}$ body weight showed $77-92 \%$ decrease in serum cholesterol, with 53-84\% LDL-cholesterol and $27-46 \%$ of triglycerides. Antiatherosclerotic activity was marked by the increase in HDL-cholesterol and the reduction in the atherogenic index. Thuja occidentalis showed a significant free-radical neutralization effect due to its ability to interfere with the absorption, degradation, and excretion of cholesterol [48].

\subsection{Radioprotective Activity}

T. occidentalis induced increased activity of TNF- $\alpha$, IL-6, and IL-1 and exhibited a protective effect against radiation [94].

In the study made by Sunila and Kuttan (2005), T. occidentalis showed a protective effect against gamma-induced toxicity in Swiss albino mice. Thus, the Thuja occidentalis alcoholic extract reduced levels of alkaline phosphatase, pyruvate transferase, and lipid peroxidation [49].

\subsection{Antipyretic Activity}

The methanolic extract of Thuja occidentalis showed antipyretic activity in rabbits. It reduces fever and normalizes body temperature at doses of $100 \mathrm{mg}$ and $200 \mathrm{mg} / \mathrm{kg}$ body, comparable to paracetamol [50].

The results of the in vitro and in vivo studies regarding the biological activities exerted by T. occidentalis are summarized in Table 3. 
Table 3. Biological activities of the Thuja occidentalis shown by in vitro and in vivo studies.

\begin{tabular}{|c|c|c|c|c|}
\hline \multirow{2}{*}{ Biological Activity } & \multirow{2}{*}{ In Vitro Studies } & \multicolumn{2}{|c|}{ In Vivo Studies } & \multirow{2}{*}{ Ref. } \\
\hline & & Animal Model & Effects & \\
\hline \multirow[t]{2}{*}{ Antioxidant } & $\begin{array}{l}\uparrow \text { DPPH, NO, O2(-), ABTS } \\
\text { scavenging activity } \\
\uparrow \text { Anti-LPO activity }\end{array}$ & - & - & {$[33,36,38,39]$} \\
\hline & $\begin{array}{c}\uparrow \mathrm{DPPH} \text { and NO scavenging activity } \\
\downarrow \downarrow \mathrm{MDA}, \uparrow \mathrm{GSH}\end{array}$ & TNBS-induced colitis mouse model & $\downarrow \mathrm{MDA}, \uparrow \mathrm{GSH}$ & [37] \\
\hline Anti-inflammatory & & TNBS-induced colitis mouse model & $\begin{array}{c}\downarrow \text { IL-6, TNF- } \alpha \text { expression } \\
\downarrow \text { COX-2 }\end{array}$ & {$[37,40]$} \\
\hline Antibacterial & $\downarrow$ Gram-negative/positive bacteria & & & [33] \\
\hline Antifungal & $\begin{array}{l}\text { inhibitory activity against the fungi } \\
\text { causing keratitis }\end{array}$ & & & [35] \\
\hline Antiviral & inhibition of HIV-1 & & & [34] \\
\hline \multirow[t]{4}{*}{ Anticancer } & $\begin{array}{c}\text { } \uparrow \text { ROS generation } \\
\uparrow \text { Cyt c and caspase-3 activation } \\
\uparrow \text { DNA fragmentation } \\
\uparrow \text { mitochondrial transmembrane } \\
\text { potential collapse } \\
\text { proapoptotic potential in the skin } \\
\text { cancer cell line A375 }\end{array}$ & & & [41] \\
\hline & $\begin{array}{l}\text { antiproliferative, proapoptotic and } \\
\text { antiangiogenic properties } \\
\downarrow \text { tumor progression }\end{array}$ & Sprague-Dawley rats & $\begin{array}{c}\downarrow \text { tumor size } \\
\text { inhibition of angiogenic markers }\end{array}$ & [42] \\
\hline & & B16F-10 melanoma cells in mice & $\begin{array}{c}\downarrow \text { IL- } 1 \beta, \text { IL- } 6 \text {, GM-CSF, TNF- } \alpha \\
\uparrow \text { IL-2 and TIMP }\end{array}$ & [43] \\
\hline & - & $\begin{array}{l}\text { B16F-10 melanoma cells in } \\
\text { C57BL/6 mice }\end{array}$ & $\begin{array}{c}\text { inhibition of lung metastasis } \\
\downarrow \text { tumor-nodule formation } \\
\downarrow \text { lung collagen hydroxyproline } \\
\downarrow \text { lung uronic acid } \\
\downarrow \text { lung hexosamine } \\
\downarrow \text { serum sialic acid } \\
\downarrow \text { serum GGT }\end{array}$ & [44] \\
\hline Hepatoprotective & - & $\begin{array}{l}\text { Acute and chronic } \mathrm{CCl}_{4} \text {-induced rats } \\
\text { liver damage }\end{array}$ & preserve normal histoarhitecture & [46] \\
\hline
\end{tabular}


Table 3. Cont

\begin{tabular}{|c|c|c|c|c|}
\hline \multirow{2}{*}{ Biological Activity } & \multirow{2}{*}{ In Vitro Studies } & \multicolumn{2}{|c|}{ In Vivo Studies } & \multirow{2}{*}{ Ref. } \\
\hline & & Animal Model & Effects & \\
\hline Gastroprotective & - & acute gastric ulcer model in rats & $\begin{array}{c}\text { antiulcer action } \\
\text { regeneration of the gastric epithelium } \\
\downarrow \text { ulcer index } \\
\downarrow \text { gastric acid production }\end{array}$ & [45] \\
\hline Antidiabetic & - & lloxan- induced diabetes in rats & $\begin{array}{c}\text { hypoglycemic } \\
\uparrow \text { GSH } \\
\text { improve lipid profile }\end{array}$ & [47] \\
\hline Antiatherosclerotic & - & cholesterol fed rats & $\begin{array}{c}\downarrow \text { cholesterol, LDL-cholesterol and } \\
\text { triglycerides } \\
\uparrow \text { HDL-cholesterol } \\
\downarrow \text { atherogenic index } \\
\text { free radical neutralization }\end{array}$ & [48] \\
\hline Radioprotective & - & $\begin{array}{l}\text { exposure of Swiss albino mice } \\
\text { to } \gamma \text {-rays }\end{array}$ & $\begin{array}{c}\downarrow \text { alkaline phosphatase } \\
\downarrow \text { glutamate pyruvate transaminase } \\
\downarrow \text { lipid peroxidation }\end{array}$ & [49] \\
\hline Antipyretic & - & $\begin{array}{l}\text { TAB vaccine-induced pyrexia } \\
\text { models in albino rabbits }\end{array}$ & $\begin{array}{c}\downarrow \text { fever } \\
\text { normalized body temperature }\end{array}$ & [50] \\
\hline
\end{tabular}

Legend: 2,2-diphenyl-1-picrylhydrazyl radical (DPPH); NO-nitric oxide; ABTS-(2,2-azino-bis-3-ethyl benzthiazoline-6-sulphonic acid); TNBS-2,4,6-trinitrobenzene sulfonic acid; LPO-lipid peroxidation; MIC-minimum inhibitory concentration; MBC-minimum bactericidal concentration; GGT—gamma glutamyl transpeptidase; GPT—glutamate pyruvate transaminase; TAB (Typhoid); cyt C-cytocrome C, $\downarrow$ increase, $\downarrow$ decrease. 
Author Contributions: Conceptualization, A.H. and C.C.; methodology, S.C., A.C., and N.K.O. investigation, S.C. and A.C.; writing-original draft preparation, S.C. and A.C.; writing-review and editing, A.H., C.C., N.K.O., S.C., A.C., and I.D.; supervision, A.H. and C.C. All authors have read and agreed to the published version of the manuscript.

Funding: This research received no external funding.

Conflicts of Interest: The authors declare no conflict of interest.

\section{References}

1. Adetutu, A.; Morgan, W.A.; Corcoran, O. Ethnopharmacological survey and in vitro evaluation of wound-healing plants used in South-western Nigeria. J. Ethnopharmacol. 2011, 137, 50-56. [CrossRef]

2. Shenoy, R.R.; Sudheendra, A.T.; Nayak, P.G.; Paul, P.; Kutty, N.G.; Rao, C.M. Normal and delayed wound healing is improved by sesamol, an active constituent of Sesamum indicum (L.) in albino rats. J. Ethnopharmacol. 2011, 133, 608-612. [CrossRef] [PubMed]

3. Sanwal, R.; Chaudhary, A.K. Wound healing and antimicrobial potential of Carissa spinarum Linn. in albino mice. J. Ethnopharmacol. 2011, 135, 792-796. [CrossRef] [PubMed]

4. Tlili, N.; Sarikurkcud, C. Bioactive compounds profile, enzyme inhibitory and antioxidant activities of water extracts from five selected medicinal plants. Ind. Crops Prod. 2020, 151, 112448. [CrossRef]

5. Builders, P.F. Introductory chapter: Introduction to herbal medicine. In Herbal Medicine; Builders, F., Ed.; IntechOpen: London, UK, 2019; pp. 1-9. [CrossRef]

6. Mirghafourvand, M.; Mohammad-Alizadeh-Charandabi, S.; Ahmadpour, P.; Javadzadeh, Y. Effects of Vitex agnus and Flaxseed on cyclic mastalgia: A randomized controlled trial. Complem. Ther. Med. 2016, 24, 90-95. [CrossRef] [PubMed]

7. Rai, M.K. Herbal medicines in India: Retrospect and prospect. Fitoterapia 1994, 65, 483-491.

8. Harvey, A.L.; Edrada-Ebel, R.; Quinn, R.J. The re-emergence of natural products for drug discovery in the genomics era. Nat. Rev. Drug Discov. 2015, 14, 111-129. [CrossRef]

9. Shen, B. A new golden age of natural products drug discovery. Cell 2015, 163, 1297-1300. [CrossRef]

10. Kew Royal Botanic Gardens. State of the World's Plants 2017. Available online: https://stateoftheworldsplants. org/2017/useful-plants.html (accessed on 12 September 2020).

11. Saroya, A.S. Herbalism, Phytochemistry and Ethnopharmacology; Science Publishers: Enfield, NH, USA, 2011; pp. 8-12.

12. De Luca, V.; Salim, V.; Atsumi, M.S.; Yu, F. Mining the biodiversity of plants: A revolution in the making. Plant. Metab. 2012, 336, 1658-1661. [CrossRef]

13. Suvarna, V.; Gujar, P.; Murahari, M. Complexation of phytochemicals with cyclodextrin derivativesAn insight. Biomed. Pharmacother. 2017, 88, 1122-1144. [CrossRef]

14. Hussain, T.; Tana, B.; Murtaza, G.; Liu, G.; Rahu, N.; Kalhoro, M.S.; Kalhoro, D.H.; Adebowale, T.O.; Mazhar, M.U.; ur Rehman, Z.; et al. Flavonoids and type 2 diabetes: Evidence of efficacy in clinical and animal studies and delivery strategies to enhance their therapeutic efficacy. Pharmacol. Res. 2020, 152, 104629. [CrossRef] [PubMed]

15. Sferrazza, G.; Corti, M.; Brusotti, G.; Pierimarchi, P.; Temporini, C.; Serafino, A.; Calleri, E. Nature-derived compounds modulating $\mathrm{Wnt} / \beta$-catenin pathway: A preventive and therapeutic opportunity in neoplastic diseases. Acta Pharm. Sin. B 2020, 10, 1814-1834. [CrossRef] [PubMed]

16. Martin, A.M.; Goya, L.; Ramos, S. Antidiabetic actions of cocoa flavanols. Mol. Nutr. Food Res. 2016, 69, 1756-1769. [CrossRef] [PubMed]

17. Siriwardhana, N.; Kalupahana, N.S.; Cekanova, M.; LeMieux, M.; Greer, B.; Moustaid, N.; Moussa, N. Modulation of adipose tissue inflammation by bioactive food compounds. J. Nutr. Biochem. 2013, 24, 613-623. [CrossRef]

18. Paulido, R.; Bravo, L.; Saura-Calixto, F. Antioxidant activity of dietary polyphenols as determined by a modified ferric reducing/antioxidant power assay. J. Agric. Food Chem. 2000, 48, 3396-3402. [CrossRef]

19. Ribeiro, A.; Ruphuy, G.; Lopes, J.C.; Dias, M.M.; Barros, L.; Barreiro, F.; Ferreira, I.C.F.R. Spray-drying microencapsulation of synergistic antioxidant mushroom extracts and their use as functional food ingredients. Food Chem. 2015, 188, 612-618. [CrossRef] 
20. Manach, C.; Williamson, G.; Morand, C.; Scalbert, A.; Remesy, C. Bioavailability and bioefficacy of polyphenols in humans. I. Review of 97 bioavailability studies. Am. J. Clin. Nutr. 2005, 81, 230-242. [CrossRef]

21. Silva, I.S.; Nicolau, L.A.D.; Sousa, F.B.M.; de Araújo, S.; Oliveira, A.P.; Araújo, T.S.L.; Souza, L.K.M.; Martins, C.S.; Aquino, P.E.A.; Carvalho, L.L.; et al. Evaluation of anti-inflammatory potential of aqueous extract and polysaccharide fraction of Thuja occidentalis Linn. in mice. Int. J. Biol. Macromol. 2017, 105, 1105-1116. [CrossRef]

22. Zhang, X.W.; Choe, Y.H.; Park, Y.J.; Kim, B.S. Effect of Korean arbor vitae (Thuja koraiensis) extract on antimicrobial and antiviral activity. Afr. J. Pharm. Pharmacol. 2014, 8, 274-277. [CrossRef]

23. Aljos, F. A monograph of Cupressaceae and Sciadopitys. Surrey: Royal Botanic Gardens. "Flora of China" editorial board (1978). Flora of China. Science 2005, 7, 318.

24. Chung, I.M.; Praven, N.; Ahmad, A. Composition of the essential oil and antioxidant activity of petroleum ether extract of Thuja koraiensis. Chem. Asian J. 2011, 23, 3703-3706.

25. Hudson, J.; Kuo, M.; Vimalanathan, S. The antimicrobial properties of cedar leaf (Thuja plicata) oil; a safe and efficient decontamination agent for buildings. Int. J. Environ. Res. Public Health 2011, 8, 4477-4487. [CrossRef] [PubMed]

26. Tsiri, D.; Graikou, K.; Pobłocka-Olech, L.; Krauze-Baranowska, M.; Spyropoulos, C.; Chinou, I. Chemosystematic value of the essential oil composition of Thuja species cultivated in Poland-antimicrobial activity. Molecules 2009, 14, 4707-4715. [CrossRef] [PubMed]

27. Guleria, S.; Kumar, A.; Tiku, A.K. Chemical composition and fungitoxic activity of essential oil of Thuja orientalis L. grown in the North-Western Himalaya. Z. Naturforsch. 2008, 63, 211-214. [CrossRef] [PubMed]

28. Baser, K.H.C.; Demirci, B.; Demirci, F.; Kocak, S.; Akinci, C.; Malyer, H.; Guleryuz, G. Composition and antimicrobial activity of the essential oil of Achillea multifida. Planta Med. 2002, 68, 941-943. [CrossRef] [PubMed]

29. Sivropoulou, A.; Nikolaou, C.; Papanikolaou, E.; Kokkini, S.; Lanaras, T.; Arsenakis, M. Antimicrobial, cytotoxic, and antiviral activities of Salvia fructicosa essential oil. J. Agric. Food Chem. 1997, 45, 3197-3201. [CrossRef]

30. Tanaka, R.; Ohtsu, H.; Iwamoto, M.; Minami, T.; Tokuda, H.; Nishino, H.; Matsunaga, S.; Yoshitake, A. Cancer chemopreventive agents, labdane diterpenoids from the stem bark of Thuja standishii (Gord.) Carr. Cancer Lett. 2000, 161, 165-170. [CrossRef]

31. Iwamoto, M.; Minami, T.; Tokuda, H.; Ohtsu, H.; Tanaka, R. Potential antitumor promoting diterpenoids from the stem bark of Thuja standishii. Planta Med. 2003, 69, 69-72. [CrossRef]

32. Iwamoto, M.; Ohtsu, H.; Tokuda, H.; Nishino, H.; Matsunaga, S.; Tanaka, R. Anti-tumor promoting diterpenes from the stem bark of Thuja standishii (Cupressaceae). Bioorg. Med. Chem. 2001, 9, 1911-1921. [CrossRef]

33. Bellili, S.; Aouadhi, C.; Dhifi, W.; Ghazghazi, H.; Jlassi, C.; Sadaka, C.; El Beyrouthy, M.; Maaroufi, A.; Cherif, A.; Mnif, W. The influence of organs on biochemical properties of tunisian Thuja occidentalis essential oils. Symmetry 2018, 10, 649. [CrossRef]

34. Gohla, S.H.; Zeman, R.A.; Bogel, M.; Jurkiewicz, E.; Schrum, S.; Haubeck, H.D.; Schmitz, H.; Hunsmann, G.; Neth, R.D. Modification of the in vitro replication of the Human Immunodeficiency Virus HIV-1 by TPSg, a Polysaccaride Fraction Isolated from the Cupressaceae Thuja occidentalis L. (Arborvitae). Haematol. Blood Transfus. 1992, 35, 140-149.

35. Asha, R.; Nisha, P.; Suneer, K.; Mythili, A.; Shafeeq Hassan, A.; Panneer Selvam, K.; Manikandan, P.; Shobana, C.S. In vitro activity of various potencies of homeopathic drug Thuja against molds involved in mycotic keratitis. Internat. J. Pharm. Pharm. Sci. 2014, 6, 555-559.

36. Nazir, M.Z.; Chandel, S.; Sehgal, A. In vitro screening of antioxidant potential of Thuja occidentalis. J. Chem. Pharm. Sci. 2016, 8, 283-286.

37. Stan, M.S.; Voicu, S.N.; Caruntu, S.; Nica, I.C.; Olah, N.K.; Burtescu, R.; Balta, C.; Rosu, M.; Herman, H.; Hermenean, A.; et al. Antioxidant and anti-inflammatory properties of a Thuja occidentalis mother tincture for the treatment of ulcerative colitis. Antioxidants 2019, 8, 416. [CrossRef]

38. Dubey, S.K.; Barta, A. Antioxidant activities of Thuja occidentalis Linn. Asian J. Pharm. Clin. Res. 2009, 2, 73-76.

39. Yogesh, K.; Ali, J. Antioxidant potential of thuja (Thuja occidentalis) cones and peach (Prunus persia) seeds in raw chicken ground meat during refrigerated $\left(4 \pm 1^{\circ} \mathrm{C}\right)$ storage. J. Food Sci. Technol. 2014, 51, 1547-1553. [CrossRef] 
40. Caruntu, S.; Olah, N.K.; Balta, C.; Rosu, M.; Mladin, B.; Hermenean, A. Thuja occidentalis mother tincture alleviate the COX-2 expression in intestinal mucosa of the TNBS-induced ulcerative colitis model in mice. Studia Univ. Vasile Goldiş Ser. Ştiinţele Vieţii 2020, 30, 145-148.

41. Biswas, R.; Mandal, S.K.; Dutta, S.; Bhattacharyya, S.S.; Boujedaini, N.; Khuda-Bukhsh, A.R. Thujone-rich fraction of Thuja occidentalis demonstrates major anti-cancer potentials: Evidences from in vitro studies on A375 cells. Evid. Based Complement. Altern. Med. 2011, 2011, 1-16. [CrossRef]

42. Torres, A.; Vargas, Y.; Uribe, D.; Carrasco, C.; Torres, C.; Rocha, R.; Oyarzun, C.; Martin, R.S.; Quezada, C. Pro-apoptotic and anti-angiogenic properties of the $\alpha / \beta$-thujone fraction from Thuja occidentalis on glioblastoma cells. J. Neurooncol. 2016, 128, 9-19. [CrossRef]

43. Sunila, E.S.; Hamsa, T.P.; Kuttan, G. Effect of Thuja occidentalis and its polysaccharide on cell-mediated immune responses and cytokine levels of metastatic tumor-bearing animals. Pharm. Biol. 2011, 49, 1065-1073. [CrossRef]

44. Sunila, E.S.; Kuttan, G. A preliminary study on antimetastatic activity of Thuja occidentalis L. in mice model. Immunopharmacol. Immunotoxicol. 2006, 28, 269-280. [CrossRef]

45. Das, S.; Rani, R. Antioxidant and gastroprotective properties of the fruits of Thuja occidentalis, Linn. Asian J. Biochem. Pharm. Res. 2013, 3, 80-87.

46. Dubey, S.K.; Batra, A. Hepatoprotective activity from ethanol fraction of Thuja occidentalis Linn. Asian J. Research Chem. 2008, 1, 32-35.

47. Dubey, S.K.; Barta, A. Antidiabetic activity of Thuja occidentalis Linn. Res. J. Pharm. Technol. 2008, 1, 362-365.

48. Dubey, S.K.; Batra, A. Role of phenolics in anti-atherosclerotic property of Thuja occidentalis Linn. Ethnobot. Leafl. 2009, 13, 791-800. Available online: https://opensiuc.lib.siu.edu/ebl/vol2009/iss6/12 (accessed on 15 September 2020).

49. Sunila, E.S.; Kuttan, G. Protective effect of Thuja occidentalis against radiation induced toxicity in mice. Integr. Cancer Ther. 2005, 4, 322-328. [CrossRef]

50. Aziz, A.; Khan, I.A.; Ahmed, M.B.; Munawar, S.H.; Manzoor, Z.; Bashir, S.; Raza, M.A. Evaluation of antipyretic activity of Thuja occidentalis Linn. in PGE1 and TAB-vaccine induced pyrexia models in rabbits. Int. J. Pharm. Sci. 2014, 4, 481-484. [CrossRef]

51. Rakotonirainy, M.S.; Lavédrine, B. Screening for antifungal activity of essential oils and related compounds to control the biocontamination in libraries and archives storage areas. Int. Biodeterior. Biodegrad. 2005, 55, 141-147. [CrossRef]

52. Pavela, R. Insecticidal activity of some essential oils against larvae of Spodoptera littoralis. Fitoterapia 2005, 76, 691-696. [CrossRef]

53. Vimalanathan, S.; Hudson, J. The Activity of Cedar Leaf oil Vapor against Respiratory Viruses: Practical Applications. J. Appl. Pharm. Sci. 2013, 3, 11-15. [CrossRef]

54. Han, X.; Parker, T.L. Arborvitae (Thuja plicata) essential oil significantly inhibited critical inflammation- and tissue remodeling-related proteins and genes in human dermal fibroblasts. Biochim. Open 2017, 4, 56-60. [CrossRef]

55. Lei, H.; Wang, Y.; Sua, C.; Liang, F.; Su, W.; Hui, M.; Shaw, P.; Luo, Y. Chemical composition and antifungal activity of essential oils of Thuja sutchuenensis, a critically endangered species endemic to China. Nat. Prod. Commun. 2010, 10, 1673-1676. [CrossRef]

56. Wang, M.; Zhao, L.; Chen, K.; Shang, Y.; Wu, J.; Guo, X.; Chen, Y.; Liu, H.; Tan, H.; Qiu, S.X. Antibacterial sesquiterpenes from the stems and roots of Thuja sutchuenensis. Bioorg. Chem. 2020, 96, 103645. [CrossRef] [PubMed]

57. Alves, L.D.S.; Figueirêdo, C.B.M.; Silva, C.C.A.R.; Marques, G.S.; Ferreira, P.A.; Soares, M.F.R.; Silva, R.M.F.; Rolim-Neto, P.J. Thuja occidentalis L. (Cupressaceae): Review of botanical, phytochemical, pharmacological and toxicological aspects. Int. J. Pharm. Sci. Res. 2014, 5, 1163-1177. [CrossRef]

58. Naser, B.; Bodinet, C.; Tegtmeier, M.; Lindequist, U. Thuja occidentalis (Arborvitae): A review of its pharmaceutical, pharmacological and clinical properties. Evid. Based Complement. Alternat. Med. 2005, 2, 69-78. [CrossRef]

59. Chang, L.C.; Song, L.L.; Park, E.J.; Luyengi, L.; Lee, K.J.; Farnsworth, N.R.; Pezzuto, J.M.; Kinghorn, A.D. Bioactive constituents of Thuja occidentalis. J. Nat. Prod. 2000, 63, 1235-1238. [CrossRef] 
60. Akkol, E.K.; Ilhan, M.; Demirel, M.A.; Keles, H.; Tümen, I.; Süntar, I. Thuja occidentalis L. and its active compound, $\alpha$-thujone: Promising effects in the treatment of polycystic ovary syndrome without inducing osteoporosis. J. Ethnopharmacol. 2015, 168, 25-30. [CrossRef]

61. Brijesh, K.; Ruchi, R.; Sanjita, D.; Saumya, D. Phytoconstituents and therapeutic potential of Thuja occidentalis. Res. J. Pharm. Biol. Chem. Sci. 2012, 3, 354-362.

62. Shimada, K. Contribution to anatomy of the central nervous system of the Japanese. Okajimas Folia Anat. Jpn. 1956, 28, 207-227. [CrossRef]

63. Saha, S.; Bhattacharjee, P.; Mukherjee, S.; Mazumdar, M.; Chakraborty, S.; Khurana, A.; Nayak, D.; Manchanda, R.; Chakrabarty, R.; Das, T.; et al. Contribution of the ROS-p53 feedback loop in thuja induced apoptosis of mammary epithelial carcinoma cells. Oncol. Rep. 2014, 31, 1589-1598. [CrossRef]

64. Nash, E.B. Expanded Works of Nash Hardcover; B Jain Publishers Pvt Ltd.: Noida, India, 2002.

65. Ellingwood, F. Agents acting upon the genitourinary organs. In The American Materia Medica, Therapeutics and Pharmacognosy; Ellingwood, F., Lloyd, J.U., Eds.; Eclectic Medical Publications: Portland, OR, USA, 1919; pp. 8-10.

66. Pudełek, M.; Catapano, J.; Kochanowski, P.; Mrowiec, K.; JanikOlchawa, N.; Czyz, J.; Ryszawy, D. Therapeutic potential of monoterpene $\alpha$-thujone, the main compound of Thuja occidentalis L. essential oil, against malignant glioblastoma multiforme cells in vitro. Fitoterapia 2019, 134, 172-181. [CrossRef]

67. Németh, E.Z.; Nguyen, H.T. Thujone, a widely debated volatile compound: What do we know about it? Phytochem. Rev. 2020, 19, 405-423. [CrossRef]

68. Harnischfeger, G.; Stolze, H. Bewährte Pflanzendrogen in Wipssenschaft und Medizin; Notamed Verlag: Bad Homburg/Melsungen, Germany, 1983; pp. 250-259.

69. Kawai, S.; Hasegawa, T.; Gotoh, M.; Ohashi, H. 4-O-Demethylatein from the branch wood of Thuja occidentalis. Phytochemistry 1994, 37, 1699-1702. [CrossRef]

70. Berlin, J.; Witte, L.; Schubert, W.; Wray, V. Determination and quantification of monoterpenoids secreted into the medium of cell cultures of Thuja occidentalis. Phytochemistry 1984, 23, 1277-1279. [CrossRef]

71. Witte, L.; Berlin, J.; Wray, V.; Schubert, W.; Kohl, W.; Höfle, G.; Hammer, J. Monound diterpenes from cell cultures of Thuja occidentalis. Planta Med. 1983, 49, 216-221. [CrossRef]

72. Neth, R.; Drize, N.; Gohla, S.; Offergeld, R.; Reski, R.; Schruhm, S. Phytotherapeutische Forschung: Thuja occidentalis L. Z. Allg. 1995, 71, 522-530.

73. EMEA-The European Agency for the Evaluation of Medicinal Products. Committee for Veterinary Medicinal Products-Thuja Occidentalis. Available online: https://www.ema.europa.eu/en/documents/mrl-report/thujaoccidentalis-summary-report-committee-veterinary-medicinal-products_en.pdf (accessed on 20 September 2020).

74. Hänsel, R.; Keller, R.; Rimpler, H.; Schneider, G. Hagers Handbuch der Pharmazeutischen, 5th ed.; Springer: Berlin, Germnay, 1994; pp. 955-966.

75. Tegtmeier, M.; Harnischfeger, G. Die Abhängigkeit des Thujongehaltes vom Extraktionsverfahren bei Zubereitungen aus Thujae herba. Pharmazie 1994, 49, 56-58.

76. Tegtmeier, M.; Harnischfeger, G. Methods for the reduction of thujone content in pharmaceutical preparations of Artemisia, Salvia and Thuja. Eur. J. Pharm. Biopharm. 1994, 40, 337-340.

77. Kopanski, L.; Keese, E.; Schnelle, G. Flavonoids from Thuja occidentalis. Planta Med. 1989, 55, 609. [CrossRef]

78. Schubert, W. Die Inhaltsstoffe von Thuja Occidentalis. Ph.D. Thesis, TU Braunschweig, Braunschweig, Germany, 1987.

79. Jahan, N.; Ahmad, M.; Mehjabeen; Zia-ul-haq, M.; Alam, S.M.; Qureshi, M. Antimicrobial screening of some medicinal plants of Pakistan. Pak. J. Bot. 2010, 42, 4281-4284.

80. Jirovetz, L.; Buchbauer, G.; Denkova, Z.; Slavchev, A.; Stoyanova, A.; Schmidt, E. Chemical composition, antimicrobial activities and odor descriptions of various Salvia sp. and Thuja sp. essential oils. Ernährung Nutr. 2006, 30, 152-159.

81. Digrak, M.; Bagci, E.; Alma, M.H. Antibiotic action of seed lipids from five tree species grown in Turkey. Pharm. Biol. 2002, 40, 425-428. [CrossRef]

82. Gupta, G.; Srivastava, A.K. In-vitro activity of Thuja occidentalis Linn. against human pathogenic aspergilli. Homoeopath. Herit. 2002, 27, 5-12. Available online: http://aohindia.in/xmlui/handle/123456789/2807 (accessed on 11 October 2020).

83. Siveen, K.S.; Kuttan, G. Thujone inhibits lung metastasis induced by B16F-10 melanoma cells in C57BL/6 mice. Can. J. Physiol. Pharmacol. 2011, 89, 691-703. [CrossRef] [PubMed] 
84. Sunila, E.S.; Kuttan, R.; Preethi, K.C.; Kuttan, G. Dynamized preparations in cell culture. Evid. Based Complement. Alternat. Med. 2009, 6, 257-263. [CrossRef] [PubMed]

85. Frenkel, M.; Mishra, B.M.; Sen, S.; Yang, P.; Pawlus, A.; Vence, L.; Leblanc, A.; Cohen, L.; Banerji, P.; Banerji, P. Cytotoxic effects of ultra-diluted remedies on breast cancer cells. Int. J. Oncol. 2010, 36, 395-403. [CrossRef]

86. Bodinet, C.; Freudenstein, J. Effects of an orally applied aqueous-ethanolic extract of a mixture of Thujae occidentalis herba, Baptisiae tinctoriae radix, Echinaceae purpureae radix and Echinaceae pallidae radix on antibody response against sheep red blood cells in mice. Planta Med. 1999, 65, 695-699. [CrossRef]

87. Aziz, A.; Khan, I.A.; Munawar, S.H.; Raza, M.A. Pharmacological evaluation of sedative activity of methanolic extract of Thuja occidentalis in mice. Int. J. Adv. Biol. Biomed. 2014, 2, 202-210.

88. Leopolsdini, M.; Russo, N.; Toscano, M. The molecular basis of working mechanism of natural polyphenolic antioxidants. Food Chem. 2011, 125, 288-306. [CrossRef]

89. Mighri, H.; Hajlaoui, H.; Akrout, A.; Najjaa, H.; Neffati, M. Antimicrobial and antioxidant activities of Artemisia herba-alba essential oil cultivated in Tunisian arid zone. Comptes Rendus Chim. 2010, 13, 380-386. [CrossRef]

90. Mahomoodally, F.; Aumeeruddy-Elalfi, Z.; Venugopala, K.N.; Hosenally, M. Antiglycation, comparative antioxidant potential, phenolic content and yield variation of essential oils from 19 exotic and endemic medicinal plants. Saudi J. Biol. Sci. 2019, 26, 1779-1788. [CrossRef] [PubMed]

91. Gohla, S.H.; Zeman, R.A.; Gartner, S.; Popovic, M.; Jurkiewics, E.; Haubeck, H.D.; Schrum, S.; Gallo, R.C.; Neth, R.D.; Hunsmann, G. Inhibition of the replication of HIV-1 by TPSg, a polysaccharide-fraction isolated from the cupressaceae Thuja occidentalis L. AIDS Res. Hum. Retrovir. 1990, 6, 131.

92. Siveen, K.S.; Kuttan, G. Augmentation of humoral and cell mediated immune responses by thujone. Int. Immunopharmacol. 2011, 11, 1967-1975. [CrossRef] [PubMed]

93. Saeed, F.; Jahan, N.; Mehjabeen, S.; Alam, S.M.; Ahmad, M. Effects of Thuja Occidentalis extract on histo-pathological parameters in rabbits treated with and without carbon tetrachloride. Br. J. Med. Health Res. 2014, 1, 16-24.

94. Bodinet, K. Immunopharmacological Studies on a Herbal Immunomodulator. Ph.D. Thesis, Universitäts-und Hansestadt Greifswald, Greifswald, Germany, 1999.

Publisher's Note: MDPI stays neutral with regard to jurisdictional claims in published maps and institutional affiliations.

(C) 2020 by the authors. Licensee MDPI, Basel, Switzerland. This article is an open access article distributed under the terms and conditions of the Creative Commons Attribution (CC BY) license (http://creativecommons.org/licenses/by/4.0/). 